\title{
Virulence factors of Escherichia coli isolated from diarrheic calves
}

[Fatores de virulência de Escherichia coli isolada de bezerros com diarréia]

\author{
E.C. Rigobelo ${ }^{1,4^{*}}$, H.J. Gamez ${ }^{2}$, J.M. Marin ${ }^{1}$, C. Macedo ${ }^{3}$, J.A. Ambrosin ${ }^{2}$, F.A. Ávila ${ }^{2}$ \\ ${ }^{1}$ Faculdade de Odontologia de Ribeirão Preto-USP \\ Avenida do Café s/n \\ 14040-904 - Ribeirão Preto, SP \\ ${ }^{2}$ Faculdade de Ciências Agrárias e Veterinárias - UNESP - Jaboticabal, SP \\ ${ }^{3}$ Faculdade de Medicina - USP - Ribeirão Preto, SP \\ ${ }^{4}$ Bolsista da CAPES
}

\begin{abstract}
One hundred seventy-three Escherichia coli strains isolated from calves from northwestern São Paulo State, having diarrhea were examined for the production of thermolabile (LT) and thermostable (ST) enterotoxins and for the presence of virulence factors associated with bovine colibacillosis. Eighty-five (49.1\%) of the E.coli strains produced toxins; 53 isolates were detected as producing STa toxin, and 9 also produced LT toxin. By PCR, 23 isolates were shown to harbor only the LT-II gene. Nine (5.2\%) isolates harbored Shiga toxin genes: four carried the stx 2 gene, four the stx 1 gene and one carried both. Three of the isolates showing stx 1 also carried the eae gene. Among the E. coli isolates examined for susceptibility to 10 antimicrobial agents, resistance to cephalothin (46.1\%), was most commonly observed, followed by resistances to tetracycline (45.7\%), trimethoprim-sulfadiazine (43.3\%) and ampicilin (41.0\%). All isolates showed resistance to at least two antimicrobial agents; multidrug resistance was quite frequently encountered. Results showed that bovine $E$. coli produces some toxins and virulence factors, some of which may be involved in human disease. The isolates showed a high level of resistance to antimicrobial agents constituting a public health concern.
\end{abstract}

Keywords: calf, diarrhea, Escherichia coli, virulence factor, antimicrobial agent

\section{RESUMO}

Cento e setenta e três cepas de Escherichia coli isoladas de bezerros com diarréia provenientes da região noroeste do estado de São Paulo foram examinadas para a produção de enterotoxinas termolábil (LT) $e$ termoestável (ST), e examinadas quanto à presença de fatores de virulência associados a colibacilose bovina. Oitenta e cinco $(49,1 \%)$ das cepas de E. coli produziram toxinas, 53 cepas foram detectadas como produtoras de toxina STa, e nove dessas cepas também produziam toxina LT. Foram identificadas pela reação em cadeia de polimerase 23 cepas portadoras do gene LT-II. Nove (5,2\%) das cepas apresentavam os genes de toxina Shiga: quatro o gene stx 2, quatro o gene stx 1 e uma cepa apresentava os dois genes. Três das cepas que apresentavam o gene stxl também possuiam o gene eae. Entre as cepas de E. coli examinadas quanto à susceptibilidade a 10 agentes antimicrobianos, a resistência à cefalotina (46,1\%) foi a mais comumente observada, seguida pelas resistências a tetraciclina (45,7\%), trimetropima-sulfadiazina (43,3\%) e ampicilina (41,0\%). Todas as cepas isoladas apresentaram resistência a pelo menos dois antimicrobianos, sendo a multirresistência detectada em elevada freqüência. Algumas toxinas e fatores de virulência, produzidos por essas cepas de E. coli podem estar

Recebido em 31 de setembro de 2004

Aceito em 16 de agosto de 2005

*Corresponding author (autor para correspondência)

E-mail: everlonagro@yahoo.com.br 
envolvidos em doenças humanas. $O$ alto nivel de resistência a agentes antimicrobianos, apresentado pelas cepas isoladas, constitue motivo de preocupação em saúde pública.

\section{Palavras-chave: bezerro, diarréia, Escherichia coli, fator de virulência, agente antimicrobiano}

\section{INTRODUCTION}

Escherichia coli is an important pathogen in bovine neonates, capable of causing intestinal and extraintestinal infections. Bovine E. coli strains can produce Shiga-like toxins (Stx), heatlabile (LT) or heat-stabile (ST) enterotoxins (Gay and Besser, 1994). Infection by enterotoxin producing E. coli (ETEC), results in diarrheic secretions due to the action of one or more enterotoxins, and can lead to dehydration and death. These bacteria may produce thermolabile (LT-I and LT-II) and thermostable (STa and STb) enterotoxins (Butler and Clarke, 1994). LTI toxin does not occur in bovine samples (Blanco et al., 1993). STa enterotoxin, which is easily detected by the suckling mouse test (Dean et al., 1972), is very common in samples from bovine cattle (Blanco et al., 1993).

The Shiga-toxin produced by E. coli strains (STEC) is similar to the Shiga-toxin produced by Shigella dysenteriae type 1. E. coli producing Stx 1 and/or 2, causes the hemorrhagic colitis (HC) and the hemolytic-uraemic syndrome (HUS) in humans. Most cases of these diseases are caused by the ingestion of foods and drinks contaminated with cattle feces, especially ground beef, undercooked hamburgers, salami, raw milk or home made raw milk cheese (Paton and Paton, 1998; Nataro and Kaper, 1998). Epidemiological investigation shown that sick as well as apparently healthy cattle constitute a natural reservoir of these microorganisms, frequently excreted in their feces, representing a possible source of infection (Blanco et al., 1996). Another virulent associated factor expressed by STEC, is a protein called intimin, responsible for the intimate attachment of STEC to intestinal epithelial cells, causing effacement lesions of the intestinal mucosa. Intimin is encoded by the chromosome gene eae, which is part of a pathogenicity island termed locus for enterocyte effacement (Oswald et al., 2000). Although the O157: H7 serotype is the dominant STEC in many parts of the world, it is now recognized that STEC strains belong to a very broad range of O:H serotypes (Paton and Paton, 1998).
Nevertheless, since non-O157 STEC are more prevalent in animals and as contaminants of foods, humans are probably more exposed to these strains, some of which have been associated with severe illness (Blanco et al., 2003).

The aim of the present study was to investigate $E$. coli isolates from diarrheic calves for the presence of possible disease-producing virulence factors, as well as possible sources of infection in humans. Antimicrobial resistance testing was also carried out for further characterize the isolates obtained.

\section{MATERIALS AND METHODS}

Fecal samples were collected between August 2001 and May 2002, from 200 diarrheic, 1-90 day old dairy calves of 6 different dairy farms in the region of Ribeirão Preto, northwestern São Paulo State, Brazil. A total of 173 E. coli colonies isolated by standard procedures, were identified by biochemical tests including the hydrogen sulphide, citrate, urease and indole tests described by Buchanan and Gibon (1994). Isolates were stored at room temperature in nutrient broth with $1.0 \%$ agar, or at $-20^{\circ} \mathrm{C}$ with $10 \%$ glycerol. Control reference strains were EDL 933 (O157: H7, stx1, stx2, eae), B62 (LTII, kindly provided by Dr. A.F. Pestana de Castro $^{1}$ ) and DH5 (negative control).

E. coli isolated in MacConkey agar were biochemicaly confirmed and submitted to slide agglutination tests using polyvalent and monovalent sera ${ }^{2}$ against serogroups $\mathrm{O} 26, \mathrm{O} 55$, O86, O111, O114, O119, O125, O126, O127, O128, O142, and O158.

For enterotoxin production, E. coli strains were grown in Evans medium (Evans et al., 1973) and filtered supernatants were tested by the suckling mouse model (Dean et al., 1972) and by the

\footnotetext{
${ }^{1}$ Instituto de Ciências Biomédicas II - USP, Brazi

${ }^{2}$ Probac do Brasil, Brazil
} 
rabbit ileal loop test (Evans et al., 1973), for detection of thermostable (ST) and thermolabile (LT) enterotoxins, respectively.

Bacterial strains, grown overnight in nutrient broth $^{3}$ at $37^{\circ} \mathrm{C}$, were pelleted by centrifugation at $1200 \mathrm{~g}$ for $10 \mathrm{~min}$, and resuspended in $250 \mu \mathrm{l}$ of sterile distilled water. Bacteria were lysed by boiling for $10 \mathrm{~min}$, lysates were centrifuged as described above and $200 \mu$ l of the supernatant were used directly as template for the polymerase chain reaction (PCR) (Wani et al., 2003). A total of $173 \mathrm{E}$. coli isolates were subjected to PCR; st $x 1$, st $x 2$ and eae genes were detected using the primers and PCR conditions described by China et al. (1996). The presence of LT-II gene was assessed by PCR amplification, using primer pairs and conditions described by Penteado et al. (2002). Amplified DNA products were separated by electrophoresis on a $1.5 \%$ agarose gel, stained with ethidium bromide and detected under ultraviolet light.

Antimicrobial susceptibility testing of bacteria was carried out by the disk diffusion method using commercial disks ${ }^{4}$, according to the guidelines of the National Committee for Clinical Laboratory Standards (National...2000). The following antimicrobial agents, loaded on the disks, were tested: ampicillin (AMP, 10 $\mu \mathrm{g}$ ), streptomycin (STR, 30 $\mu \mathrm{g}$ ), kanamycin (KAN, $10 \mu \mathrm{g})$, tetracycline (TET, 30 $\mathrm{g}$ ), trimethoprimsulfadiazine (TMP, 25 $\mu \mathrm{g}$ ), gentamicin (GEN, $10 \mu \mathrm{g})$, nalidixic acid (NAL, $10 \mu \mathrm{g})$, cephalothin

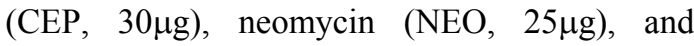
nitrofuranthoin (NIT, 30 $\mu \mathrm{g}$ ).

\section{RESULTS}

Among the $173 \mathrm{E}$. coli isolates analysed, the somatic antigen (serogroup) was determined in 120 of them. The most frequently identified serogroups were O114 (28 isolates), O119 (27 isolates), $\mathrm{O} 111$ (18 isolates) and O86 (13 isolates); only serogroups $\mathrm{O} 142$ and $\mathrm{O} 158$ were not found among the isolates (Table 1).

Examination of the $173 \mathrm{E}$. coli isolates by the suckling mouse model resulted in the detection of 53 isolates producing thermostable

\footnotetext{
${ }^{3}$ Sigma Chemical, USA

${ }^{4}$ Cecon, Brazil
}

enterotoxin (STa). Nine of the STa-producing isolates also produced thermolabile (LT-II) enterotoxin, detected in 32 isolates by the rabbit ileal loop test and confirmed by PCR as LT-II positive strains (Table 1).

All isolates were submitted to multiplex PCR to detect stx 1 , stx 2 and eae genes. STEC were isolated from $9(5.2 \%)$ fecal samples. The distribution of stx genotype and eae are summarized in Table 1, which also shows that the eae gene was predominantly associated with the stx 1 gene. PCR showed that 4 of the STEC isolates carried the $s t x 1$ gene, 4 possessed the st $x 2$ gene and 1 isolate carried both stx 1 and stx 2 genes.

When tested against 10 antimocrobial agents, $E$. coli isolates most frequently were resistent to cephalothin (46.1\%), tetracycline (45.7\%), trimethoprim-sulfadiazine $\quad(43.3 \%)$, and ampicillin (41.0\%) (Table 2). All isolates showed resistance to at least two antimicrobal agents. Multidrug resistance was quite common and the percentage of resistance of the isolates to 2-4, 57 and 8-10 agents were respectively, $38.4 \%$, $27.6 \%$ and $34.0 \%$.

\section{DISCUSSION}

Since colibacillosis is an important cause of economic loss on farms, detailed studies of the virulence factors produced by $E$. coli strains in farm animals are needed. Colibacillosis is common in Brazil, as some studies have reported (Leomil et al., 2003; Salvadori et al., 2003). Among the $173 \mathrm{E}$. coli isolates studied from northwestern of São Paulo State, 85 (49.1\%) were found to be positive for at least one of the virulence factors examined, a result similar to that reported by Salvadori et al. (2003). A wide range of serogroups in cattle has already been reported (Holland et al., 1999; Wani et al., 2003), some only in bovines, and others, like O26, O103, O111 and $\mathrm{O} 157$ both in bovines and humans (Paton and Paton, 1998). Saridakis et al. (1997) reported the isolation of E. coli serogroups O26, O114, O119, O125, O128, $\mathrm{O} 142$ and $\mathrm{O} 158$ from diarrheic calves in Brazil, in agreement with the results reported here. 
Table 1. Toxigenic Escherichia coli strains isolated from calves with diarrhea in Brazil

\begin{tabular}{lcc}
\hline Toxin & $\mathrm{N}^{\circ}(\%)$ of $E$. coli isolates & O serogroups \\
\hline Stx1 & $1(0.6)$ & $114,119,125$ \\
Stx2 & $4(2.3)$ & 55,126 \\
Stx1 and eae & $3(1.7)$ & 128 \\
Stx1 and stx2 and eae & $1(0.6)$ & 114 \\
STa & $44(25.4)$ & $26,55,86,111,114,119,125,126,127,128$ \\
LT-II & $23(13.2)$ & $26,55,86,111,114,119,125,126,127,128$ \\
STa and LT-II & $9(5.2)$ & $26,55,86,111,114,119$ \\
\hline
\end{tabular}

ETEC is a major cause of diarrhea in travelers to (sub-) tropical areas, as well as in animals. ETEC strains that cause diarrhea by producing LT, ST or both can be detected by testing isolates for enterotoxin production by bioassay (Dean et al., 1972; Evans et al., 1973). Fifty-three (30.6\%) STa positive isolates were found in the present study, a result higher than those reported by Lazaro et al. (1994) and Salvadori et al. (2003). Some of the isolates, $5.2 \%$ (Table 1), produced both enterotoxins ST and LT, a result also described by Dalton et al. (1999) in the USA, for a human fecal sample. Salvadori et al. (2003) found $8.3 \%$ of the LT-II gene in E. coli isolates from diarheic calves in the State of Mato Grosso do Sul in Brazil, a result lower than the $18.5 \%$ of the $E$. coli isolates described here.

High frequency of STEC has been observed in isolates from diarrheic and non-diarrheic calves (Leomil et al., 2003). Studies carried out in different countries have shown that $10-80 \%$ of cattle may carry STEC (Blanco et al., 1996; Cobbold and Desmarchelier, 2000). STEC was found in 9 isolates $(5.2 \%)$; this value is smaller than that reported by Leomil et al. (2003), of $12.7 \%$ of STEC strains, and by Salvadori et al. (2003), 16.1\%, both from Brazil.

Some investigators have underlined the strong association between carriage of the eae gene and the capacity of the STEC strains to cause severe human disease, especially HUS (Boerlin et al., 1999). However, the association of eae and stx genes in STEC isolates for the pathogenesis of diarrheic calves remains controversial. Wieler et al. (1996) determined the prevalence of both virulence factors in STEC as of $70.0 \%$; Cobbold and Desmarchelier (2000) described only $0.8 \%$ positive eae's among STEC isolates. Salvadori et al. (2003) and Leomil et al. (2003) reported a frequency of eae carriage of $21.2 \%$ and $41.0 \%$ respectively, among STEC isolates from calves in Brazil; in the present study, however, only a small number of isolates had this gene $(2.3 \%)$. Wieler et al. (1996) described that most of the STEC strains from diarrheic calves harbor st 1 genes along with the eae gene. Leomil et al. (2003) also reported predominant association of stx 1 and eae genes; in the present study the eae gene was also found associated with stx 1 , but also with the stx 2 gene.

For more than four decades it has been a common practice on farms the usage of antimicrobial agents for disease prevention and growth promotion of animals. The widespread use of antimicrobial agents would select for resistance and may have promoted the increasing frequency of STEC strain's multidrug resistance in bovines. This could result in an increase of STEC population and, perhaps greater, shedding which, could lead to greater contamination of animal food products (Zhao et al., 2001). One hundred percent of the isolates tested in this study were resistant to two or more of the antimicrobial agents tested. Cephalothin and tetracycline showed the highest rates of resistance, $46.1 \%$ and $45.7 \%$ respectively (Table 2 ). Thirty-four percent of the isolates showed resistance to 8-10 antimicrobial agents; a rather high rate that agrees with the results reported by Lazaro et al. (1994) among diarrheic calves in Rio de Janeiro, Brazil They found $80.0 \%$ of the isolates showing multidrug resistance. Indirect selection for multiresistant strains will contribute to the increase of emerging antimicrobialresistant pathogens, and facilitate the spread of these mobile resistance elements to other bacteria. Increased surveillance and development of adequate prevention in public health measures are therefore required strategies.

In conclusion, these results show that bovine $E$. coli produce some toxins and have virulence factors some of which may be involved in human diseases. 
Table 2. Antimicrobial resistance patterns in 173 Escherichia coli strains isolated from diarrheic calves in Brazil

\begin{tabular}{lc}
\hline Antimicrobial agent & $\begin{array}{c}\text { Frequency of resistance } \\
(\%)\end{array}$ \\
\hline Cephalothin & 46.1 \\
Tetracycline & 45.7 \\
Trimethoprim-sulfaadiazine & 43.3 \\
Ampicillin & 41.0 \\
Nitrofuranthoin & 34.1 \\
Streptomycin & 32.4 \\
Neomycin & 26.0 \\
Kanamycin & 23.1 \\
Gentamycin & 21.4 \\
Nalidixic acid & 13.8 \\
\hline
\end{tabular}

\section{REFERENCES}

BLANCO, M.; BLANCO, J.; BLANCO, J.E. et al. Enterotoxigenic, verotoxigenic and necrotoxigenic Escherichia coli isolated from cattle in Spain. Am. J. Vet. Res., v.54, p.14461451, 1993.

BLANCO, M.; BLANCO, J.E.; BLANCO, J. et al. Prevalence and characteristics of human and bovine verotoxigenic Escherichia coli strains isolated in Galicia (north western Spain). Europ. J. Epidemiol., v.12, p.13-19, 1996

BLANCO, M.; BLANCO, J.E.; MORA, A. et al. Serotypes, virulence genes, and intimin types of Shiga toxin (verotoxin)-producing Escherichia coli isolates from healthy sheep in Spain. J. Clin. Microbiol., v.41, p.1351-1356, 2003.

BOERLIN, P.; MCEWEN, S.A., BOERLINPETZOLD, F. et al. Association between virulence factors of Shiga toxin-producing Escherichia coli and disease in humans. J. Clin. Microbiol., v.37, p.497-503, 1999.

BUCHANAN, R.E.; GIBON, N.E. Bergey's Manual of Determinative Bacteriology 9.ed. Baltimore, MD: Williams \& Wilkins, p.787, 1994.

BUTLER, D.G.; CLARKE, R.C. Diarrhoea and dysentery in calves. In GYLES C.L. (Ed.) E. coli in domestic animals and humans. Wallingford: Cab International, 1994. p.91-116.

CHINA, B.; PIRSON, V.; MAINIL, J. Typing of bovine attaching and effacing Escherichia coli by multiplex in vitro amplification of virulenceassociated genes. Appl. Envirom. Microbiol., v.62, p.3462-3465, 1996.
COBBOLD, R.; DESMARCHELIER, P. A longitudinal study of Shiga-toxigenic Escherichia coli (STEC) prevalence in three Australian dairy herds. Vet. Microbiol., v.71, p.125-137, 2000.

DALTON, C.B.; MINTZ, E.D.; WELLS, J.G. et al. Outbreaks of enterotoxigenic Escherichia coli infections in American adults: a clinical and epidemiologic profile. Epidemiol. Infect., v.123, p.9-16, 1999.

DEAN, A.G.; CHING, Y.; WILLIAMS, R.G. et al. Test for Escherichia coli enterotoxin using infant mice: application in a study of diarrhea in children in Honolulu. J. Infect. Dis., v.125, p.407-411, 1972.

EVANS, D.G.; EVANS, D.J.J.R.; PIERCE, N.F. Differences in the response of rabbit small intestine to heat-labile and heat-stable enterotoxin of Escherichia coli. Infect. Immunol., v.7, p.873-880, 1973.

GAY, C.C.; BESSER, T.E. Escherichia coli septicaemia in calves. In GYLES, C.L (Ed.). Escherichia coli in domestic animals and humans. Wallingford: CAB International, 1994. p.75.

HOLLAND, R.E.; WILSON, R.A.; HOLAND, M.S. et al. Characterization of eae Escherichia coli isolated from healthy and diarrhoeic calves. Vet. Microbiol., v. 66, p.251-263, 1999.

LAZARO, N.S.; RODRIGUES, D.L.; MENDONÇA, C.L. et al. Escherichia coli enteropatogênica isolada de bezerros no estado do Rio de Janeiro, Brasil. Rev. Bras. Med. Vet., v.16, p.55-61, 1994.

LEOMIL, L.; AIDAR-UGRINOVICH, L.; GUTH, B.E.C. et al. Frequency of Shiga toxinproducing Escherichia coli (STEC) isolates among diarrheic and non-diarrheic calves in Brazil. Vet. Microbiol., v.97, p.103-109, 2003.

NATARO, J.P.; KAPER, J.B. Diarrheagenic Escherichia coli. Clin. Microbiol. Rev., v.11, p.142-201, 1998.

NATIONAL COMMITTEE FOR CLINICAL LABORATORY STANDARDS Performance Standards for Antimicrobial Disk Susceptibility Tests. Approved standard, 7.ed. Wayne, PA: NCCLS M2-A7, 2000.

OSWALD, E.; SCHMIDT, R.; MORABITO, S. et al. Typing of intimin genes in human and 
animal enterohemorrhagic and enteropathogrnic Escherichia coli characterization of a new intimin variant. Infect. Immunol., v.68, p.64-71, 2000 .

PATON, J.C.; PATON, A.W Pathogenesis and diagnosis of Shiga toxin-producing Escherichia coli infection. Clin. Microbiol. Rev., v.11, p.450479, 1998.

PENTEADO, A.S.; UGRINOVICH, L.A.; BLANCO, J. et al. Serobiotypes and virulence genes of Escherichia coli strains isolated from diarrheic and healthy rabbits in Brazil. Vet. Microbiol., v. 89, p. 41-51, 2002.

SALVADORI, M.R.; VALADARES, G.F.; LEITE, D.S. et al. Virulence factors of Escherichia coli isolated from calves with diarrhea in Brazil. Braz. J. Microbiol., v.34, p.230-235, 2003.

SARIDAKIS, H.O.; EL GARED, S.A.; VIDOTO, M.C. et al. Virulence properties of
Escherichia coli strains belonging to enteropathogenic (EPEC) serogroups isolated from calves with diarrhea. Vet. Microbiol., v.54, p.145-153, 1997.

WANI, S.A.; BHAT, M.A.; SAMANTA, I. et al. Isolation and characterization of Shiga toxinproducing Escherichia coli (STEC) and enteropathogenic Escherichia coli (EPEC) from calves and lambs with diarrhea in India. Let. Appl. Microbiol., v.37, p.121-126, 2003.

WIELER, L.H.; VIELER, E.; ERPENSTEIN, C. et al. Shiga toxin-producing Escherichia coli strains from bovines: association of adhesion with carriage of eae and other genes. J. Clinic. Microbiol., v.34, p.2980-2984, 1996.

ZHAO, S.; WHITE, D.G.; AYERS, S. et al. Identification and characterization of integronmediated antibiotic resistance among Shiga toxin-producing Escherichia coli isolates. Appl. Envirom. Microbiol., v.67, p.1558-1564, 2001. 